\title{
Penerapan Teknik Data Mining untuk Clustering Armada pada PT. Siaga Transport Indonesia Menggunakan Metode k-Means
}

\author{
Nuzul Hikmah ${ }^{1)}$, Dyah Ariyanti 2), Melista Sugesti ${ }^{3)}$ \\ Universitas Panca Marga Probolinggo 1) \\ n.hikmah1807@upm.ac.id
}

\begin{abstract}
Abstrak - PT. Siaga Transport Indonesia adalah perusahaan yang bergerak dibidang expedisi. Armada menjadi aset penting untuk perusahaan yang bergerak di bidang ini. Beratnya muatan yang diangkut, jauhnya jarak yang ditempuh, dan usia armada menjadi faktor penyebab kerusakan armada. Hal ini berpengaruh terhadap potensi armada. Untuk itu diperlukan analysis clustering menggunakan metode $k$ means untuk mengetahui armada yang potensial dan yang kurang potensial. Clustering merupakan teknik pengelompokkan objek yang didasarkan pada kemiripan antar objek dalam satu cluster. K-means merupakan metode clustering yang mempunyai kemampuan mengelompokkan data dalam jumlah cukup besar dengan waktu komputasi yang relatif cepat dan efisien. Dalam penelitian ini sistem akan mengelompokkan 33 armada dengan menggunakan variabel biaya operasional, tahun kendaraan, produktivitas armada dan kilometer armada menjadi 3 kelompok dengan kategori cluster armada berpotensi rendah, sedang dan tinggi. Dari hasil akhir sistem diketahui cluster 1 atau armada dengan potensi rendah ada 7 armada, cluster 2 atau armada dengan potensi sedang ada 14 armada, cluster 3 atau armada dengan potensi tinggi ada 12 armada. Pengujian dilakukan dengan metode silhouette coefficient dengan rentang variasi nilai yang dihasilkan yaitu dibawah nol sampai dengan 0,9.
\end{abstract}

Kata kunci: Data Mining, Clustering, K-means

\section{PENDAHULUAN Latar Belakang}

PT. Siaga Transport Indonesia merupakan perusahaan yang bergerak dibidang expedisi. Tujuan umum didirikannya sebuah perusahaan adalah untuk menghasilkan barang, jasa yang menjadi kebutuhan konsumen. Armada menjadi aset penting untuk perusahaan yang bergerak di bidang ini sehingga harus diperhatikan kondisi setiap armada. Beratnya muatan yang diangkut dan jauhnya jarak yang ditempuh oleh setiap armada, dapat membuat armada mengalami kerusakan. Usia armada juga menjadi faktor penyebab kerusakan armada. Hal ini sangat berpengaruh terhadap kinerja armada karena produktifitas armada akan menurun, sehingga keuntungan yang didapat oleh perusahaan akan mengalami peurunan pula. Untuk mengatasi hal tersebut, pimpinan perusahaan melakukan regenerasi terhadap kendaraan dengan menjual armada yang telah mengalami penurunan potensi. Dalam menentukan armada yang akan dijual, perlu dilakukan identifikasi berdasarkan beberapa faktor yang mempengaruhi kondisi kendaraan. Faktor ini meliputi tahun kendaraan yang berkaitan dengan usia kendraan, produk-tifitas kendaraan dalam satu tahun terakhir, biaya operasional dan kilometer kendaraan. Salah satu cara untuk mempermudah dalam pengelompok-kan armada adalah dengan menggunakan teknik data mining yaitu dengan klaster analisis (analysis cluster).

\section{DASAR TEORI}

Knowledge discovery in databases (KDD)

Knowledge discovery in databases (KDD) adalah keseluruhan proses non-trivial untuk mencari dan mengidentifikasi pola (pattern) dalam data, dimana pola yang ditemukan bersifat sah, baru, dapat bermanfaat dan dapat dimengerti. Proses KDD itu ada 5 tahapan yang dilakukan secara terurut, yaitu:

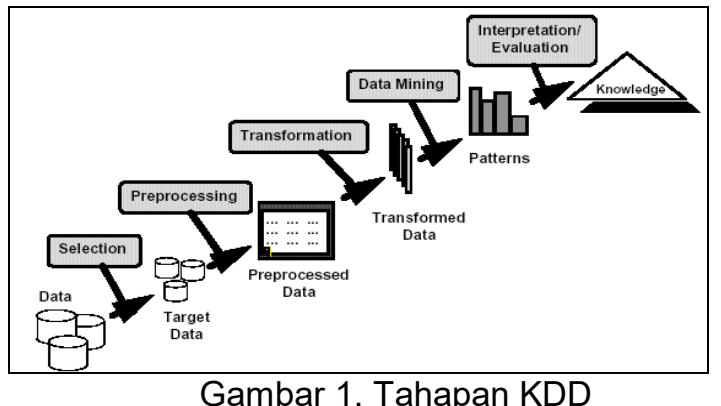

a. Data selection

Pemilihan (seleksi) data dari sekumpulan data operasional.

b. Pre-processing

Sebelum proses data mining dilaksanakan, perlu dilakukan proses cleaning pada data yang menjadi 
fokus KDD. Proses cleaning mencakup antara lain membuang duplikasi data, memeriksa data yang inkonsisten, dan memperbaiki kesalahan pada data.

\section{c. Transformation}

Coding adalah proses transformasi pada data yang telah dipilih, sehingga data tersebut sesuai untuk proses data mining.

d. Data mining

Data mining adalah proses mencari pola atau informasi menarik dalam data terpilih dengan menggunakan teknik atau metode tertentu.

e. Interpretation/evalution

Pola informasi yang dihasilkan dari proses data mining perlu ditampilkan dalam bentuk yang mudah dimengerti oleh pihak yang berkepentingan.

\section{Clustering}

Clustering adalah proses mengelompokkan objek berdasarkan informasi yang diperoleh dari data yang menjelaskan hubungan antar objek dengan prinsip untuk memaksimalkan kesamaan antar anggota satu kelas dan meminimumkan kesamaan antar kelas-nya. Penerapan metode clustering menghasilkan pengetahuan berupa penentuan beberapa cluster catatan data yang memiliki kemiripan atribut.

\section{K-Means}

Algoritma K-Means merupakan sebuah metode sederhana, cepat dan efisien untuk pengelompokkan data dalam suatu angka spesifik dari cluster, yaitu $k$. Algoritma K-Means dimulai dengan pemilihan secara acak $\mathrm{K}, \mathrm{K}$ disini merupakan banyaknya cluster yang ingin dibentuk. Kemudian tetapkan nilai-nilai $\mathrm{K}$ secara random, untuk sementara nilai tersebut menjadi pusat dari cluster atau biasa disebut dengan centroid. Hitung jarak setiap data yang ada terhadap masingmasing centroid menggunakan rumus Euclidian hingga ditemukan jarak yang paling dekat dari setiap data dengan centroid. Klasifikasikan setiap data berdasarkan kedekatannya dengan centroid. Lakukan langkah tersebut hingga nilai centroid tidak berubah (stabil).

\section{Algoritma K-Means}

1. Menentukan jumlah cluster

2. Menentukan nilai centroid dalam menentukan nilai centroid untuk awal iterasi, nilai awal centroid dilakukan secara acak.

3. Menghitung jarak antara titik centroid dengan titik tiap objek Untuk menghitung jarak tersebut dapat menggunakan Euclidean Distance, yaitu

$$
D_{e}=\sqrt{\left(x_{i}-s_{i}\right)^{2}+\left(y_{i}-t_{i}\right)^{2}}
$$

4. Pengelompokan objek untuk menentukan anggota cluster adalah dengan memperhitungkan jarak minimum objek.

5. Kembali ke tahap 2, lakukan perulangan hingga nilai centroid yang dihasilkan tetap dan anggota cluster tidak berpindah kecluster lain.

\section{Metode Pengujian Silhouette Coefficient}

Metode ini merupakan metode validasi cluster yang menggabung-kan metode cohesion dan separation. Penggunaan metode ini untuk menilai kualitas serta kekuatan cluster. silhouette coefficient dari tiap objek dalam suatu cluster adalah suatu ukuran yang menunjukkan seberapa ketat data dikelompokkan dalam cluster tersebut. Dalam hal ini ditinjau pula seberapa baik suatu objek ditempatkan dalam suatu cluster tertentu. Berikut ini merupakan ukuran nilai silhouette menurut Kaufman dan Rousseeuw:

Tabel 1. Ukuran Nilai Silhouette

\begin{tabular}{|l|l|}
\hline $\begin{array}{l}\text { Nilai silhouette } \\
\text { coefficient (SC) }\end{array}$ & Keterangan \\
\hline $0.7<\mathrm{SC}<=1$ & strong structure \\
\hline $0.5<\mathrm{SC}<=0.7$ & medium structure \\
\hline $0.25<\mathrm{SC}<=0.5$ & weak structure \\
\hline $\mathrm{SC}<=0.25$ & no structure \\
\hline
\end{tabular}




\section{METODE PENELITIAN}

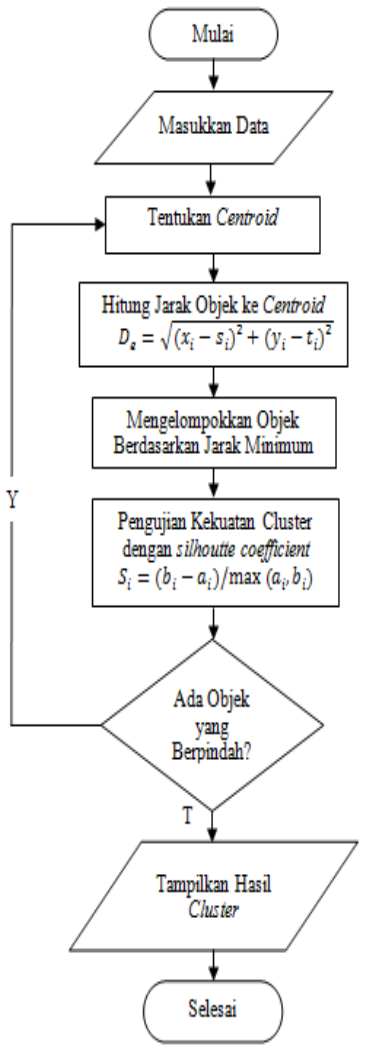

Gambar 2. Diagram Alir Sistem

Tahap pertama adalah input data, data yang digunakan adalah data training yang telah melalui tahap pre-processing sehingga menjadi data dengan format excel yang dapat diproses dalam sistem clustering data. Tahap selanjutnya adalah me-nentukan titik centroid awal dimana titik centroid awal ditetukan dari hasil perhitungan ratarata data sampel. Selanjutnya adalah me-nghitung jarak antara titik centroid dengan titik tiap objek mengguna-kan persamaan eucli-dean distance. Tahap selanjutnya adalah me-ngelompokkan objek berdasarkan jarak ter-kecil objek ke titik centroid. Semakin kecil jarak objek ke centroid, semakin baik objek tersebut berada di kelas centroid-nya. Langkah terakhir adalah pengujian, dimana pada tahapan ini pengujian dilakukan menggunakan metode silhoutte coefficient. jika hasil perhitungan baru berbeda dengan hasil perhitungan sebelumnya, maka ulangi untuk menentukan centroid baru dengan persamaan sebagai berikut:

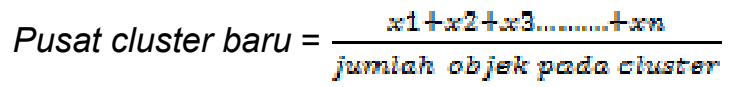

Namun apabila hasil prhitungan baru sama dengan hasil perhitungan sebelumnya, maka selesailah perhitungannya dan tampilkan hasil cluster terakhir.

\section{Use Case Diagram}

Pengguna sistem ini sebanyak satu orang. Fungsi yang dapat dijalankan oleh pengguna pada sistem ini adalah fungsi memasukkan data. Data yang dimaksud disini adalah data training pada 33 kendaraan. Fungsi berikutnya adalah menentukan titik pusat. Titik pusat ini didapat dari hasil ratarata dari masing-masing variabel pada data sampel. Kemudian fungsi proses Clustering dimana pada fungsi ini dilakukan perhitungan jarak objek dengan titik centroid menggunakan metode Euclidean Distance dan pengujian dengan metode silhouette coefficient untuk menilai kualitas serta kekuatan cluster. Fungsi proses cluster sangat bergantung pada fungsi penentuan titik pusat.

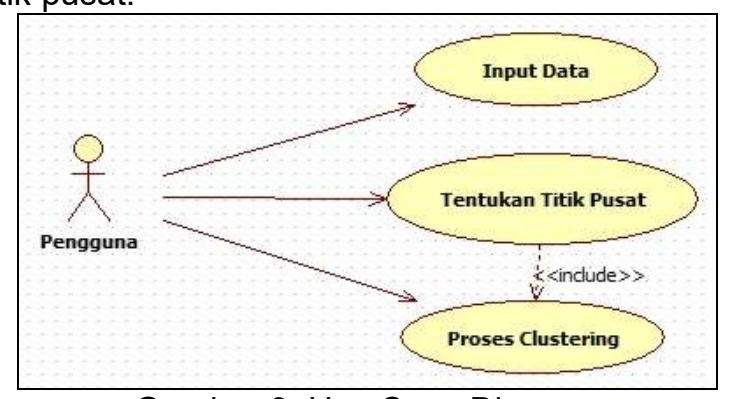

Gambar 3. Use Case Diagram

\section{Sequence Diagram}

Sequence Diagram menggambarkan urutan interaksi antar objek ketika satu use case dilakukan, sehingga sequence diagram sebaiknya sebanyak use case nya. Ada 3 tahap Sequence diagram untuk sistem ini, yaitu proses pertama adalah adalah input data, selanjutnya proses menentukan titik centroid yang dilakukan oleh user dan terakhir adalah proses clustering. Masing-masing Sequence Diagram dapat dilihat sebagai berikut:

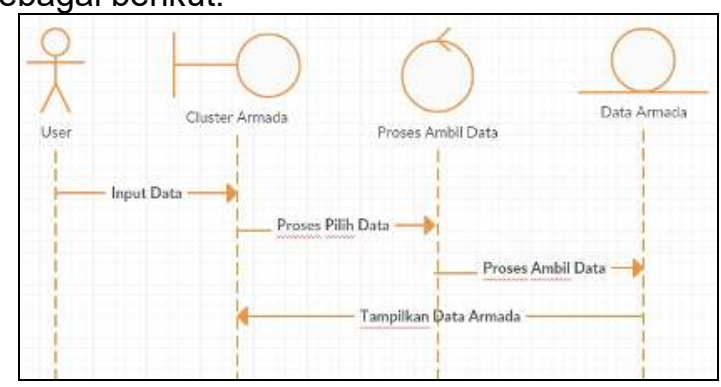

Gambar 4. Sequence Diagram input data 


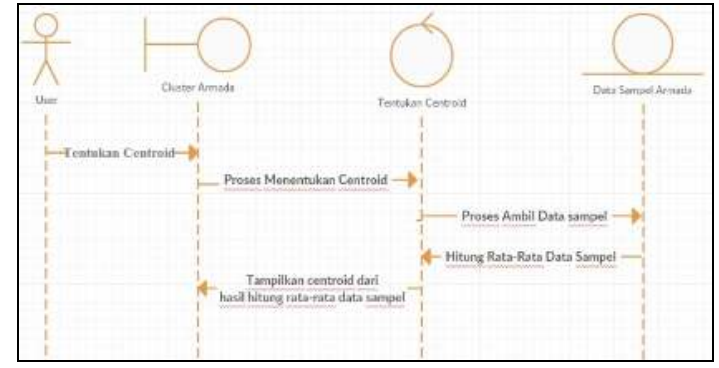

Gambar 5. Sequence Diagram centroid

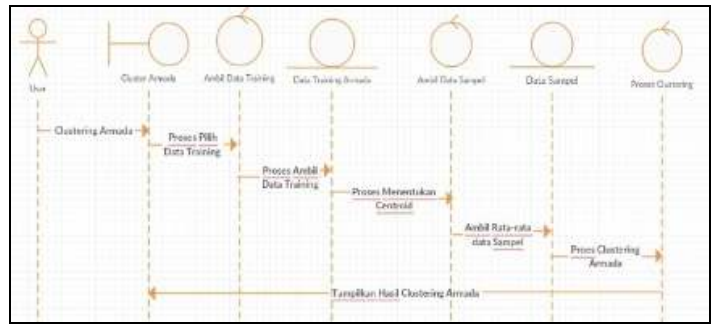

Gambar 6. Sequence Diagram proses Cluster

\section{HASIL DAN PEMBAHASAN \\ Pre-Processing Data}

Sebelum melakukan data mining perlu dilakukan pre-processing terhadap data sampel dan data uji yang masing-masing berjumlah kurang lebih 3500 data dalam satu tahun. Tujuan dari proses preprocessing data ini adalah untuk memastikan data yang akan diolah di data mining adalah data yang baik dan siap diproses pada data mining. Data sampel diambil dari januari 2016 samapi dengan desember 2016. Sedangkan data uji diambil dari bulan Januari 2017 sampai dengan Desember 2017.

\section{Proses Clustering K-Means}

1. Langkah awal metode k-means yaitu menentukan jumlah cluster yang diinisialkan dengan " $\mathrm{K}$ ". Dalam hal ini penulis menentukan ada 3 kategori cluster. Dengan ketentuan untuk cluster 1 adalah armada dengan potensi rendah, cluster 2 adalah armada dengan potensi sedang dan cluster 3 merupakan armada dengan potensi tinggi.

2. Selanjutnya langkah kedua dalam algoritma $k$ means adalah menentukan centroid. Centroid diambil dari hasil rata-rata masing-maing variabel pada data sampel. Dimana data sampel dibagi menjadi 3 golongan berdasarkan tahun kendaraan sebagai berikut:

a. Kendaraan yang telah berumur lebih dari atau sama dengan 9 tahun, maka kendaraan tersebut dikategorikan sebagai kendaraan yang kurang potensial.

b. Kendaraan yang telah berumur lebih dari atau sama dengan 5 tahun dan kurang dari 9 tahun, maka kendaraan tersebut dikategorikan sebagai kendaraan dengan potensi sedang.

c. Kendaraan yang telah berumur kurang dari atau sama dengan 4 tahun, maka kendaraan tersebut dikategorikan sebagai kendaraan dengan potensi tinggi.

Sehingga didapat hasil centroid seperti pada tabel berikut ini:

Tabel 2. Centroid Pertama

3. Selanjutnya menghitung jarak tiap objek ke titik centroid menggunakan persamaan euclidean distance sebagai berikut:

$$
D\left(x_{n}, c_{n}\right)=\sqrt{\left(x_{i}-s_{i}\right)^{2}+\left(y_{i}-t_{i}\right)^{2}}
$$

Hasil dari perhitungan jarak objek ke centroid untuk iterasi pertama adalah sebagai berikut:

Tabel 3. Perhitungan Euclidean Distance

\begin{tabular}{|l|l|l|l|l|}
\hline \multirow{2}{*}{ No } & \multirow{2}{*}{$\begin{array}{l}\text { No. } \\
\text { Pol }\end{array}$} & \multicolumn{3}{|c|}{ Perhitungan Jarak Objek Ke } \\
\cline { 3 - 5 } & & \multicolumn{1}{|c|}{ C1 } & \multicolumn{1}{|c|}{ C2 } & \multicolumn{1}{c|}{ C3 } \\
\hline 1 & 8552 & 28052512 & 37930651 & 42967325 \\
\hline 2 & 8003 & 12166621 & 22047001 & 27085814 \\
\hline 3 & 8943 & 7963153 & 2021365 & 7012790 \\
\hline 4 & 8445 & 3278503 & 13158434 & 18197996 \\
\hline 5 & 8523 & 2420003 & 12300125 & 17339906 \\
\hline$\ldots$ & $\ldots$ & $\ldots$ & $\ldots$ & $\ldots$ \\
\hline
\end{tabular}

4. Tahap selanjutnya adalah mengelompokkan objek berdasarkan jarak minimum pada setiap iterasi untuk mengetahui objek menempati cluster ke berapa.

Tabel 4. Jarak Minimum

\begin{tabular}{|c|c|c|c|}
\hline No & No. Pol & $\begin{array}{c}\text { Jarak } \\
\text { Minimum }\end{array}$ & Cluster \\
\hline 1 & 8552 & 28052512 & 1 \\
\hline 2 & 8003 & 12166621 & 1 \\
\hline 3 & 8943 & 2021365 & 2 \\
\hline 4 & 8445 & 3278503 & 1 \\
\hline 5 & 8523 & 2420003 & 1 \\
\hline$\ldots$ & $\ldots$ & $\ldots$ & $\ldots$ \\
\hline
\end{tabular}

Apabila hasil cluster pada iterasi yang baru tidak sama dengan hasil cluster pada iterasi sebelumnya maka, tentukan centroid baru dan hitung kembali jarak objek dengan centroid yang baru. Apabila hasil cluster pada iterasi yang baru sama dengan hasil cluster pada 
iterasi sebelumnya maka, proses clutering berakhir dan lanjutkan untuk pengujian kualitas cluster tersebut.

5. Untuk menilai kualitas serta kekuatan cluster dilakukan pengujian dengan menggunakan metode silhoutte coefficient.

\section{Pengujian Sistem}

Langkah-langkah untuk menjalankan aplikasi pada tampilan Menu Utama adalah sebagai berikut:

1. Memilih data training yang telah melalui preprocessing data dan siap di lakukan proses clustering.

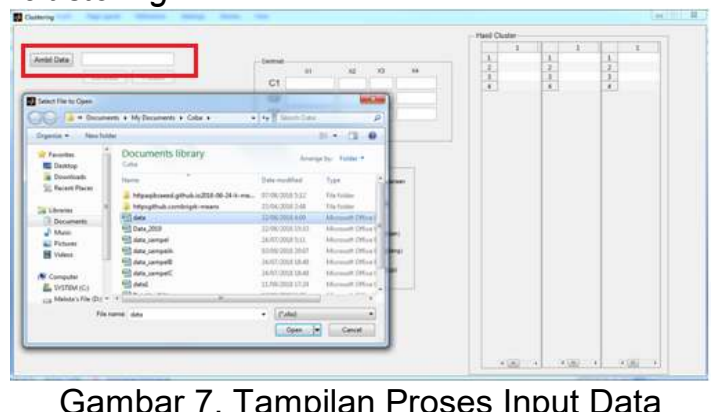

2. Mengambil centroid dari pergitungan rata-rata data sampel yang hasilnya akan ditampilkan pada panel centroid

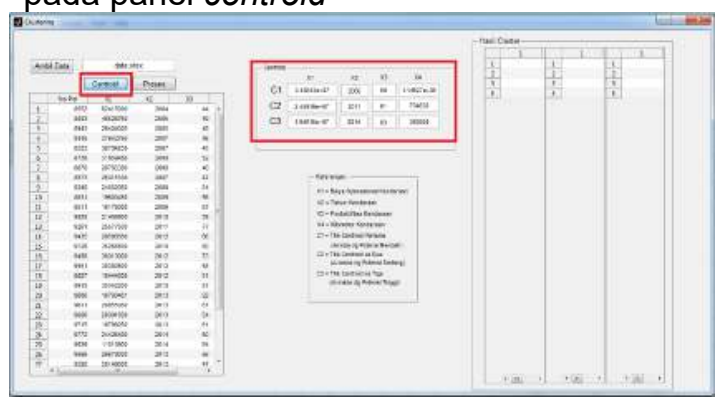

Gambar 8. Tampilan Proses Centroid

3. Hasil dari proses clutering ini akan ditampilkan pada panel hasil cluster.

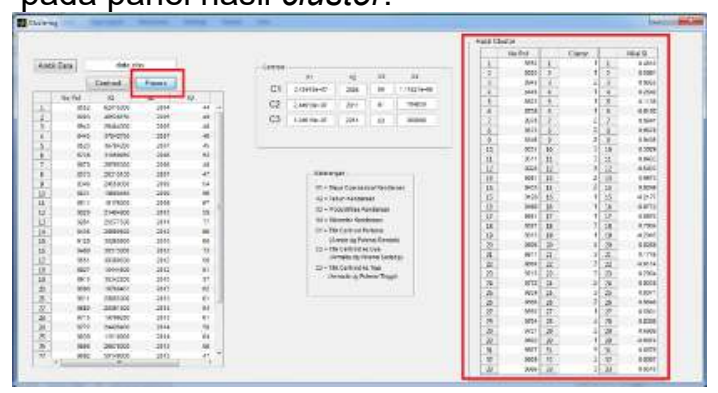

Gambar 9. Tampilan Proses Clustering

\section{KESIMPULAN}

Berdasarkan hasil penelitian yang penulis lakukan tentang clustering armada menggunakan metode k-means dalam mengelompokkan armada disimpulkan bahwa:

1. Metode k-means clustering dapat diterapkan pada data clustering armada di PT.Siaga Trannsport Indonesia sehingga metode ini sangat membantu dalam pengambilan keputusan untuk menjual armada

2. Objek penelitian dikelompokkan kedalam 3 (tiga) kelompok dengan hasil pengelompokkan sebagai berikut:

a. Cluster 1 untuk kategori kendaraan dengan potensi rendah beranggotakan 7 armada.

b. Cluster 2 untuk kategori kendaraan dengan potensi sedang beranggotakan 14 armada.

c. Cluster 3 untuk kategori kendaraan dengan potensi tinggi beranggotakan 12 armada.

3. Dari hasil pengelompokkan armada menggunakan metode $k$-means pada iterasi terakhir, diketahui bahwa armada yang berada pada cluster 1 ada 7 data dengan 4 (empat) data yang error atau tidak sesuai. Sehingga nilai akurasi yang diperoleh pada pengujian ini sebesar $87,88 \%$.

\section{PUSTAKA}

Andayani, Sri. 2007. Pembentukan cluster dalam Knowledge Discovery in Database dengan Algoritma K-Means.

Bahar, Apriadi. 2016. Penentuan Strategi Penjualan Alat-Alat Tattoo Di Studio Sonyx Tattoo Menggunakan Metode K-Means Clustering

Fahrudin, Alex. Bambang Eka Purnama dan Berliana Kusuma Riasti. 2011. Pembangunan Sistem Informasi Layanan Haji Berbasis Web Pada Kelompok Bimbingan Ibadah Haji Ar Rohman Mabrur Kudus

Firdaus, Gita Rosyada. 2017. Clustering Untuk Pemetaan Daerah Potensial Budidaya Perikanan Di Jawa Timur Menggunakan Algoritma Fuzzy C-Means

Handoko, Koko. 2016. Penerapan Data Mining Dalam Meningkatkan Mutu Pembelajaran Pada Instansi Perguruan Tinggi Menggunakan Metode K-Means Clustering (Studi Kasusu di Program Studi TKJ Akademi Komunitas Solok Selatan).

Hendini, Ade. 2016. Pemodelan UML Sistem Informasi Monitoring Penjualan Dan Stok Barang (Studi Kasus: Distro Zhezha Pontianak)

Hidayat, Rahman., Rochid Wasono dan Moh. Yamin Darsyah. 2017. Pengelompokan Kabupaten Di Jawa Tengah Menggunakan Metode K-Means dan Fuzzy C-Means.

Hikmawati, Nur Lailatul. 2017. Pengenalan Ucapan Menggunakan Metode MFCC dan Algoritma Backpropagation. 
J, W, Satzinger., Jackson R. B dan Burd S. D. 2011. Systems Analysis and Design in a Changing World, Sixth ed.

L, Kaufman and P. J. Rousseuw. 1990. Finding Groups in Data. New York: John Wiley \& Sons.

Murti, Mikael Aditya Wahyu Krisna. 2017. Penerapan Metode K-Means Clustering Untuk Mengelompokan Potensi Produksi Buah-Buahan di Provinsi Daerah Istimewa Yogyakarta.

Purba, Yugi Trianto. 2008. Penerapan Data Mining Untuk Menemukan Pola Antara Nilai Ujian Saringan Masuk Terhadap Indeks Prestasi.

Saragi, Cytra Sari Rewati. 2017. Penerapan Metode K-Means Untuk Clustering Mahasiswa Berdasarkan Parameter Nilai Magang Dan Job Description Pada Jurusan Teknik Informatika Politeknik Negeri Batam.

Siregar, Gellysa Urva dan Helmi Fauzi. 2015. Pemodelan UML E-Marketing Minyak Goreng

Zahrotun, Lisna. 2015. Analisis Pengelompokan Jumlah Penumpang Bus Trans Jogja Menggunakan Metode Clustering K-Means Dan Agglomerative Hierarchical Clustering (Ahc). 